\title{
ARTICLES
}

\section{Restructuring Electricorp: the labour process, profit, technology and work organisation}

\section{Carl Ammon*}

This paper presents a case study of the restructuring of Electricorp, focusing specifically on the central North Island hydro stations managed by the corporation's Production Division. It does not necessarily cover all of the changes occurring within Electricorp's other divisions or subsidiaries. While the utilisation and development of new technologies is a key facet of the restructuring process, other factors are of equal, if not greater, significance - namely, new forms of work organisation (i.e. staffing composition and more 'flexible' work practices) and a narrowed emphasis on profitability. This paper examines all these factors in the context of the blueprint for the commercially oriented restructuring of the New Zealand Electricity Department set out in the 1986 Taskforce Report. It also views the restructuring exercise from the perspective of labour process theory, discussing the reorganisation plan as a managerial strategy for control over the labour process and looking at worker resistance to these managerial initiatives.

\section{Corporatisation}

During the 1970s, the role of the state in the framework of macro-economic policy came under critical focus. State intervention in economic activity was fast losing favour (Williams, 1988, pp.111-120) and at a political level neo-classical economic policy was growing in influence. In England there was Thatcherism and in the United States there was Friedmanism. New Zealand took some time to respond to international circumstances and it was not until the election of the Labour Government in 1984 that a free market orientation became obvious.

On December 12, 1985, the newly elected Labour Government released an 'Economic Statement' that set out an official policy on reforms to the state sector. To quote the Minister of Finance: 
the public sector needs to be adapted to meet the management needs of a modern economy.

The "adaptations" were, in a nutshell, a redefinition of the role of state departments. The model of private sector business organisation was to be adopted for all state departments that could function as trading entities. Moreover, the environment within which these corporations were to operate was to be constructed according to the canons of the free market. According to the Minister, improved efficiency and lower taxes would be the result of this exercise.

Five key imperatives were set out for this reform of management practice:

A. Responsibility for non-commercial functions will be separated from the majo trading state owned enterprises.

B. Managers of state owned enterprises will be given a principal objective of running them as successful business enterprises.

C. Managers will be given responsibility for decisions on the use of inputs and on the pricing and marketing of their output within the performance and objectives agreed with Ministers and Parliament for their results.

D. The advantages and disadvantages which state owned enterprises have, including unnecessary barriers to competition, will be removed so that commercial criteria will provide a fair assessment of managerial performance.

E. Individual state owned enterprises will be reconstituted on a case by case basis in a form appropriate to their commercial purposes under the guidance of Boards comprising, generally, members appointed from the private sector.

(Government Economic Policy Statement, 1985)

These policy directives clearly display the profit motive at work. While the goals of improved efficiency and greater accountability were behind the directives, a further motive was the desire to sell off state assets and divert the funds toward paying off New Zealand's was the desire to sell off state assets and divert the funds toward paying off New Zealand's foreign creditors. In effect, through the State Owned Enterprises Act (1986), the Government set up a corporation to buy assets from the Government. The price paid is debt to be repaid over three years (Waikato Times, 1988). The new corporation must then secent moves aimed at privatisation of these secure a return on this in trend one step further.

The Hon. David Lange PM commented on the economic policy shift in a speech given at Massey University in 1987:

By the end of the 1970's this approach [interventionism] was increasingly called into question... in all the OECD countries. It was plain by the late 1970's that a new approach to economic management was needed (New Zealand Public Service Association, 1988, p.6).

A paper released by the New Zealand Public Service Association summarizes the Lange government's orientation to the role of the state in the following terms:

The specific features of Labour's attack on the state are well known to all, they have included corporatisation of state departments, removal of subsidies and have included corporatisation of state departments, removal of subsidies and tariffs, deregulation of other aspects
flexibility, etc. (NZPSA, 1988, p.4).

Walsh's (1988, pp.179-190) study of industrial relations in the state-owned corporations highlights the quite radical shift in the industrial relations climate arising out of the structural and policy changes associated with corporatisation. The new corporate managers had clear objectives in mind about reshaping the relationships that had developed under the centralised and consultative regime administered by the State Services under the centralised and consultative regime administered by the State Services different attitudes to those of the previous departmental heads. The comments of Electricorp's chairman, John Fernyhough, are indicative of the changed perspective:

...there was not an employer-employee relationship in the government organisations. You were not able to gauge your own people, you were not responsible for them. They were responsible to the SSC so there was no real nexus between those leading the organisation and those working for it, no sease of identity or accountability which you would get in the private sector (NZ Listener, May 14, 1987)

Electricorp was set up in line with the policies covered above. A Board was appointed and a taskforce commissioned to reshape the organisation along the commercial lines suited to its purpose. The blueprint for this new commercial enterprise was set out in the taskforce report produced by a team of consultants and released to the board of Electricorp in February, 1987. Its terms of reference were simple:

1. Advise the Board if the present and intended organisation structure is appropriate for a commercial organisation. ${ }^{1}$

2. As necessary, develop a new organisation structure

3. Identify the staff required for the new organisational structure; broadly the number, location and skills.

The report focused primarily on the need to improve cost efficiency by a major restructuring involving a shift from service goals to profit goals. Conveniently, the old New Zealand Electricity Department organisation had reached a stage of development where a surplus of generation capacity existed. As a consequence, Electricorp was in a position to move away from developmental work and concentrate instead on improving efficiencies within a relatively static growth environment.

As the name implies, the NZED was a division of the Ministry of Energy and as such a part of the public service. It was a largely self-sufficient organisation which under a head and regional office structure built, operated and maintained power stations, transmission lines and sub-stations. It also supplied power to local authorities and some major industrial users. Like most other public service departments it operated as an autonomous entity with little in the way of functional links to outside organisations. Staff were employed in a diverse range of activities (e.g. painters, landscape architects, storekeepers, plumbers, metallurgists, biologists, cooks, etc.) and numbered around 5200 prior to corporatisation.

Electricorp soon began the process of large scale "disemployment", reducing staff by some 20 percent in the course of building its new organisational structure. The bulk of job cuts were achieved by contracting out, casualisation of the workforce, dropping certain functions and a general pruning out of staff and certain levels of the hierarchy. Structurally, Electricorp was reorganised into a corporate head office, two major divisions charged respectively with producing and marketing electricity, a design and construction

1 As implied, there was already a restructuring plan in existence. This was, however designed for a public service based organisation and, although it recommended some of the rationalisations eventually adopted by the Electricorp taskforce, was thus considere inadequate for the explicitly commercial perspective of the new corporation. 
division, the supply authority for the Southland area, and a central co-ordination company for the NZEDificant change to the for the nation structure under Electricorp, however, was the separation of its largely undifferentiated activities of construction, sales, distribution and production into separate business units that had autonomous management, accounting, personnel and funding systems. Local managers were given much more decision-making power and were provided with resources (e.g. engineers and accountants) to aid their decisions. Power generation went to the Produrtion division; distribution to Transpower Ltd; marketing to the Marketing division; Production division and development and construction the four business units while still maintaining overall co-ordination of the highly integrated electricity generation and distribution system.

\section{The restructuring programme}

Apart from the reshaping outlined above, specific changes occurred within Electricorp the to the organisation of work. Three main inter-relating programme and will be discussed individually in some depth. They are:

I. Staffing levels - both in number and skill composition.

II. Work organisation.

III. Technology

Staffing levels

Staffing levels were reduced both numerically (by 1100 or 19 percent of employees the relative numbers of specific occupations within the nation

a) Removing one tier of line management within the maintenance hierarchy

b) Utilising the available workforce in a more 'efficient' fashion, i.e., having a smaller workforce perform the same workload as was handled previously by more workers - see the discussion of work organisation below for specific examples.

c) Using contract workers to cover periods of peak demand, thus cutting back on the staff levels required for normal activities. This method is as yet only used to a limited degree for peripheral works (e.g. building and maintenance of grounds, etc.) and in some maintenance work on more integral plants such as transmission gear. This latter work is being done by the casual labour force of the Power Design Build Group as opposed to the Production Group's permanen workfore based at particular facilities.

D Introducine local level and moving most of the engineering and technical staff from the head office to group (e.g. North Island Hydro Group) and area offices. This in effect moved staff geographically rather than reducing total numbers. There was, however, net increase in certain accounting, personnel and technical groups and a net decrease in various skilled (e.g. painters and plumbers) and semi-skilled (e.g. skilled labourers, clerks and powerhouse attendants) workers.

\section{Work organisation}

One recommendation of the taskforce was to use the available maintenance workforce (o enable a greater labour inpu over a given period of time. A "round-the-clock" staff meant tasks could be completed more quickly and efficiently, for example by planning plant service during periods of low power demand. Previously, "outages of plant" meant lost revenues and reduced flexibility power demand. Previously, "outages of plant" meant lost revenues and reduced flexibility
in total system terms. The added cost of overtime payments for using the labour force in total system terms. The added cost of overtime payments for using the labour force
beyond its previous 40 hour, 7 am to $4 \mathrm{pm}$, Monday to Friday work pattern was also avoided. This plan, however, was aimed at thermal facilities rather than hydro stations due to their higher maintenance input and continuous generation (i.e. baseload) characteristics. It is as yet unrealised.

The group of workers who run the power stations (i.e. operators) already worked 7 day, 24 hour shifts. Changes to this group's pattern of work included:

i) Reduced numbers on shifts, achieved by the removal of powerhouse attendant from shiftwork and transfer of their duties in the main to the day workforce of skilled labourers. This entailed giving operators added duties previously performed by attendants. This improved utilisation of the reduced labour force has been implemented at all hydro facilities, but, as I will note later it, was the source of considerable worker resistance.

ii) Plans to implement remote control operating activities to both centralise this function, thus reducing numbers by minimising multiplication of functions and to remove one or two shifts for operators during the night. Roving operators would be used during the night to attend to emergencies and other problems at facilities during these unstaffed periods. These roving operators would service stations within a large geographical area, again reducing net staff requirements. This aspect of the taskforce plan is as yet largely unrealised, but a model already exists at the Tokaanu power station with its remote control system for the underground Rangipo power station, and in the use of roving operators in the Tuai group of stations.

Another aspect of work reorganisation was to make the workforce more mobile. To achieve this, workers were deployed over larger areas to ensure that their labour was utilised to its greatest possible extent. Previously, a given workforce had a defined area within which it worked and movements outside that area were rare. Now, under-utilisation is avoided by moving workers to where the work is. A specific example of this process is the use within a group of stations of service and maintenance workers who were previously tied to a single station. The new structure of Area Groups is critical here in terms of optimising workforce deployment, as well as in the longer term plans for remote control from central points (refer to the Taskforce Report, 1987, pp.121-2 for details of the planned Area centred organisation).

Multi-skilling was introduced as another enhanced marginal utility move. Under the new structure, with its new job specifications, the demarcation lines of workers craf domains are being dissolved, allowing for the increased utilisation of a given workforce. For example, operations personnel are now required to do jobs that were previously the domain of another category of worker, the powerhouse attendant. Labour flexibility has resulted in reduced staff levels and considerable saving in wage costs. The use of more flexible designations enables staff to undertake tasks by the criteria of their urgency and the amount of under-utilised time the particular worker has - i.e. the use of senior fitters (electrical and mechanical) to perform the hands on work of other fitters while also shouldering the supervisory and administrative duties of the now extinct 'trades supervisors' who occupied the tier above "hands on" tradespersons within the old NZED hierarchy.

Technology

Developments in technology include the use of micro-processor based remote contro 
of both monitoring and operational functions for a group of individual power stations from a central location; and the application of sophisticated computer modelling to maximise total system efficiency (i.e. water usage, plant maintenance and generation levels). At present these are largely hypothetical, but preliminary action includes sending engineering staff overseas to study facilities employing this sort of technology and the overseas recruitment of staff with experience of these systems. The accepted strategy is to introduce the new technology over a 5 to 7 year period.

The relatively simple method of hydro-electric generation makes remote control operation technically feasible and potentially cost effective: if a live plant fails, it can be shut down, double-checked by a roving operator and returned to service immediately or reinstated the next day by the day shift work force. Most hydro power stations have several separate generating units which operate independently and the loss of one or more units is of minimal impact on the overall generating capacity going into the national grid system - especially at night when demand for power is low.

As noted earlier, a first generation version of the remote control form of operation is already in place within the Tokaanu Area of the North Island Hydro Group. Research is well underway on the mechanics and feasibility of implementing remote control and automated operations systems at several stations within the newly formed Area Operating Groups. In addition, automation is planned for some routine functions still done manually (e.g. greasing of bearings and circuit breaker switching). A degree of automation automation is also being river hydros). This automation would entail mechanisms that increase generation in line with increased lake levels and so on.

The most viable groupings for remote control are those within a workable geographic area (in terms of communication and travel time) and where a common water system prevails, making co-ordination possible and even necessary. The area operating concept is thus a key factor informing the new structure with its management centres and mobile workforces (Taskforce Report, pp.121-2)). All that remains to be done to the present system is to introduce remote control and redeploy the affected staff - or make them redundant if that is cheaper.

\section{The labour process and the struggle for control}

The Electricorp blueprint for efficiency was a strategy to control the labour process. ${ }^{2}$ NZED's corporatisation provided the environment within which such a strategy could be effected, in that it radically redefined the legal, institutional and attitudinal systems that structured the old order. Some of the key objectives of the restructuring programme were:

(i) To redefine attitudes and relationships. For example, the change in focus from public service to corporate profit; the extension of traditional craft domains (e.g operators doing the work of the former attendants); the change in attitudes to operators doing the work of the former attendants); the change in attitudes to
safety (e.g. sole charge operators working at night); and the idea of mobility (e.g. area workforces as opposed to station-based workforces)

(ii) To reduce labour cost by cutting the workforce (by close to 20 percent) and to relocate other workers to new locations to satisfy the new division of labour. To casualise previously permanent employment to enhance labour utilisation vary the price paid to workers for their labour power (i.e. by getting fewer workers to do more work pro rata for no more pay, and by getting lower paid workers to do work previously done by more highly paid staff (i.e. skilled labourers replacing powerhouse attendants))

(iii) To shed areas of activity that were not central to the key role of producing electricity for sale (e.g. to close hydro villages and get out of the provision of staff housing where possible).

(iv) To provide the correct human resources by changing the occupational mix of the workforce to ensure that the corporate objectives were achieved (e.g. bringing in new skills to facilitate technological change and building up support staff in accounting and personnel).

In all of these examples of control over the labour process the motive of Electricorp's management was to improve profitability via reduced wage costs and other associated overheads (e.g. housing, superannuation, etc.). This type of control derives from the desire to be cost effective. However, a more manifestly political mode of control is also at work here: the desire to minimise the potential of workers to resist managerial prerogatives.

\section{Conflict and resistance}

Hyman (1980) notes that a good deal of managerial control is accepted unquestioningly by workers as the way things are, as the master/servant relationship. Sometimes tensions do become evident in mild forms of resistance or non-co-operation with management requirements. At the other end of the spectrum, however, are the overt struggles that are either channeled through mechanisms for dispute resolution or are fought out in a variety of arenas: in the political domain via lobbying and propaganda campaigns; or in the industrial arena via strikes, suspensions, and other forms of coercive behaviour. In Electricorp, behaviour from both ends of the spectrum was visible. To clarify the following discussion of the conflict and resistance which took place within Electricorp, I have broken the topic into three levels, namely the national political; the macroorganisational; and the workplace.

\section{National political}

Although it continued throughout the restructuring process, the political form of interaction was most evident during the early stages of corporatisation. The main agents involved were the state unions and the left-wing of the Labour party, although the public debate involved a variety of other groupings (e.g. the political opposition and women's groups). By its very nature, this form of conflict/resistance is rather generalised and abstract. Activity took the form of lobbying MPs, caucuses and cabinet as well as internal pressure in the party organisation of the government. A public propaganda campaign was promoted by the unions in defence of public services which raised criticisms of the benefits that the government was claiming would flow from its reform programmes. Various forms of high profile public protest were also fostered by the union (e.g. rallies and protests).

\section{Macro-organisational}

Partly because of failure to affect government policies, the macro-organisational level of conflict/resistance took a primary role in the struggle. It focused on specific workplace related matters which were being channeled through the formal structures of the NZPSA and Electricorp's industrial relations and public relations sections.

Electricorp had undergone its corporate restructuring in a form slightly different to the 
other state departments in that all staff were given jobs in the corporation and only subsequently did the restructuring exercise affect them. A transition determination was subsequently did the restructuring a provided for carry over conditions of employment and provisions to deal with surplus staff. This agreement was temporary and was at odds with the desires of corporate management who wanted radical changes in bargaining structures, conditions and union coverage.

The barely submerged differences between the union and the corporation soon became evident as restructuring proceeded. It became clear that major staff cuts were coming as well as other upheavals in the organisation. Electricorp's policy of not negotiating with the PSA exacerbated these tensions and direct confrontation became inevitable. Late in 1987 the PSA served notice of progressive generation reductions - a strategy designed to 1987 the PSA served notice of progressive generation reductions - a strategy designed to
gradually put pressure on Electricorp through the costs of rescheduling generation to meet demand. The scheme also maximised the publicity for the dispute, thus bringing pressure to bear on the political masters of the corporation.

This dispute was cut short when Electricorp obtained an interim ex parte injunction. The attitude of the workforce to this management initiative was to ignore it until the current generation freeze had ended. Management in turn responded by issuing warning letters which the union refused to recognise. To compound this legal stalemate, the PSA letters which the union refused to recognise. To compound this legal stalemate, the PSA
was successful in gaining an interim injunction against Electricorp for a breach of its agreement covering the restructuring exercise. The hiatus following these events was put to use in framing an administrative agreement to cover restructuring. It achieved a variety of protections for workers facing job losses, relocations or other major changes. It also afforded the union greater involvement in managing the changes that lay ahead, although this involvement was in reality little more than a watching (policing) brief.

The administrative agreement in effect ended the major conflict. What remained was tinkering with a largely predetermined course of events. At this juncture the processes of conflict/resistance entered the level of the workplace.

\section{Workplace conflict/resistance}

The climate of opinion that existed at the workplace level following the strikes, suspensions, injunctions and the administrative agreement was a mixture of relief, confusion and disappointment. Relief, since most workers and middle managers were glad to step back from the brink of open confrontation and to have some guidelines available for coming to terms with the changes facing them as day to day problems. Confusion, since the form and consequences of restructuring were not fully known. While the blueprint for restructuring was on hand, its practical translation was being done by regional and local managers who had to fly by the seat of their pants for much of the time.
Disappointment, because many workers felt that they had been sold short by the administrative agreement. The ongoing doubts over jobs, housing, working conditions etc. also damaged the morale of the workforce. The strong rumours of a second wave of change associated with privatisation added to the atmosphere of uncertainty.

The most significant factor shaping the micro-level interaction between workers and their managers was the availability of voluntary severance and early retirement. In the final analysis more workers wanted this solution to restructuring than there were tickets available. Many workers were ready to take the cash and try their luck elsewhere. This one fact left the union in a problematic situation as the new structure was effectively shor of staff, so the spectre of forced unemployment did not arise apart from some individual and localised cases. This is not to say that workers were happy with the turn of events, but rather that out of pragmatism they took their best option. In some instances staff who knew they were in short supply took advantage of that fact and used their severance option as a trump card to resist certain management initiatives (e.g. operations staff refused to sign new job appointment letters that contained variations on their former dutie and in so doing forced management to employ added staff and to promise a definite time- frame for the introduction of automated greasing systems.

In other instances, workers who were surplus delayed taking severance knowing management could not force them to leave as redundancy proper was not allowed for in the PSA-Electricorp agreements. This was an annoyance to managers who did not have a slot for such people and who saw them as unproductive and costly. In this sort of situation and in others where workers were required to relocate a degree of horse-trading ensued to tip the scales one way or another.

While severance did give workers an out, many felt constrained to stay on under different conditions as their livelihoods, homes and social ties were all linked to being employed by the corporation. The situation of thousands of other workers made redundant or simply unemployed in the country at the time instilled a degree of caution in the minds of many workers.

If the fear of job loss, dislocation and economic difficulties was a "stick" to condition the responses of workers, the use of incentives had the effect of a "carrot" to retain and motivate workers. To attract workers to new locations compensation was offered. Some employees taking on new jobs were given salary increments and other workers who took on distinctly more onerous jobs received pay rises.

The longer term implications of technological changes related to centralised computerised remote control are still issues between management and the union. However, this situation is still too remote to have any tangible manifestations.

\section{Conclusion}

In the corporatisation and restructuring of the NZED, I have argued, management was preoccupied with controlling the labour process in order to increase the profitability of their operations. In their attempts to achieve the primary pursuit of profit, managemen was forced to deal with the political implications of the conflict of interest resulting from their initiatives.

Overall, the objectives of management were achieved. However, management had to make compromises along the way, and will continue to need to accommodate the requirements of its workforce. The union did achieve a degree of success in ameliorating the adverse impact of change on its members and in demonstrating to the senior management of Electricorp that the union cannot be ignored with impunity. The changes introduced via restructuring and the ongoing technology based changes will create new sets of interests that will provide the raw materials for ongoing conflict, resistance and compromise.

\section{References}

Brighton Labour Process Group (1979) Capital and class 1:3-42.

Hyman, R (1980) In Esland, G and Salaman, D (eds) The politics of work and occupations Milton Keynes, Open University Press.

Taskforce Report (1986) Electricorp, December.

Waikato Times (1988) April 2.

Walsh, P (1988) The struggle for power and control in the new corporations New Zealand journal of industrial relations 13(2):179-190. 
Williams, A (1988) The labour market in a deregulated economy New Zealand journal of industrial relations 13(2): 111-126. 